\title{
Strategies to improve the fertility of fresh and frozen donkey semen
}

\author{
José Victor de Oliveira, Pedro Victor de Luna Freire Oliveira, \\ Cely Marini Melo e Oña, Priscilla Nascimento Guasti, \\ Gabriel Augusto Monteiro, Yamê Fabres Robaina Sancler da Silva, \\ Patrícia de Mello Papa, Marco Antônio Alvarenga, \\ Jose Antonio Dell'Aqua Junior, Frederico Ozanam Papa*
}

Department of Animal Reproduction and Veterinary Radiology, São Paulo State University, UNESP, Botucatu, São Paulo, Brazil

\section{A R T I C L E I N F O}

\section{Article history:}

Received 8 October 2014

Received in revised form 14 December 2015

Accepted 15 December 2015

\section{Keywords:}

Equus asinus

Donkey jack

Semen cryopreservation

Insemination dose

Jennies

\begin{abstract}
A B S T R A C T
Fertility rates of donkey semen in jennies are lower compared to mares. The aims of this study were to evaluate different sperm cryopreservation methods and insemination strategies to improve the fertility of donkey semen in jennies. Three experiments were performed: (1) the comparison of two freezing methods of donkey semen (conventional method and automated method); (2) the determination of a suitable insemination dose of fresh donkey semen for jennies and mares; and (3) the influence of the semen deposition site on fertility of jennies inseminated with frozen donkey semen. For experiment 1, no differences were observed in total motility, angular velocity, curvilinear velocity, straight-line velocity, and plasma membrane integrity between samples frozen with the conventional (Styrofoam box) and the automated method (TK 4000C). However, the automated method provided higher values of progressive motility and rapid cells in frozen-thawed samples in comparison with the conventional method $(\mathrm{P}<0.05)$. For experiment 2 , mares were bred using $500 \times 10^{6}$ fresh sperm $(\mathrm{M})$; and jennies using $1 \times 10^{9}$ (J1) or $500 \times 10^{6}$ fresh sperm (J5). Pregnancy rates in M, J1, and J5 were $93 \%(14 / 15), 73 \%(11 / 15)$, and $40 \%(6 / 15)$, respectively. When using different insemination doses, $500 \times 10^{6}$ or $1 \times 10^{9}$ sperm, no significant difference was observed in pregnancy rates of mares (M, 14/15) and jennies (J1, 11/15). Furthermore, there was no significant difference between the two insemination doses in jennies. However, with an insemination dose of $500 \times 10^{6}$ fresh sperm, the pregnancy rates were significantly higher in mares $(\mathrm{M}, 14 / 15)$ than in jennies $(\mathrm{J} 5,6 / 15 ; \mathrm{P}<0.05)$. For experiment 3 , the inseminations were carried out in the uterine body (UB) or in the uterine horn of jennies with frozenthawed donkey semen. No pregnancies were achieved with inseminations performed in the UB (0/12). The pregnancy rate for uterine horn group was $28.26 \%(13 / 46)$ and thus significantly higher than the UB group $(0 \% ; 0 / 12 ; \mathrm{P}<0.05)$. In conclusion, the automated method showed higher values on progressive motility and rapid cells parameters compared to the conventional method and can be used as an alternative for freezing donkey semen. The increase in the number of sperm cells per insemination dose using fresh donkey semen improved the fertility rates in jennies. The deep horn inseminations using frozen-thawed donkey semen increased the pregnancy rate in jennies, and the multiple inseminations may be an option to improve the fertility rates of donkey semen in jennies.
\end{abstract}

(c) 2016 Elsevier Inc. All rights reserved.

\footnotetext{
* Corresponding author. Tel./fax: +55 1438116249.

E-mail address: papa@fmvz.unesp.br (F.O. Papa).
} 


\section{Introduction}

Donkey species are bred around the world, and there is a particular interest for the production of hybrids in many countries [1-3]. The resulting hybrid of the mating of a horse (Equus caballus) with a donkey (Equus asinus) results in highly desirable products that combine the best features of the two species in a single animal [2], which has great physical strength and required strength for animal traction [1,3].

The use of frozen semen in artificial insemination (AI) represents the main tool for genetic improvement of most domestic animals. The advantages of frozen semen include lower transportation costs, continuous availability of semen, decrease in the risk of transmission of venereal diseases, and increase of the genetic pool [4]. In addition, the use of frozen semen could be an alternative for the preservation of endangered donkey breeds. There are approximately 185 donkey breeds worldwide [5], and the number of individuals in certain breeds is very low and demands an intervention to guarantee their survival [6,7].

However, the fertility rate of frozen semen in AI programs is lower than fresh or cooled semen [8-10]. The freezing process includes factors that are extremely harmful to sperm cells, such as changes of temperature, osmotic and toxic stress caused by exposure to cryoprotective agents, and the intracellular ice formation $[10,11]$. These conditions seriously affect sperm functionality and viability, leading to reduced sperm longevity in the female genital tract $[12,13]$. Moreover, the use of frozen semen induces a stronger inflammatory reaction in the uterus than fresh semen in mares [14].

The studies on the basis of the cryopreservation of stallion sperm have been reported for more than 50 years [15-19], however, the researches involving donkey semen are recent [20-24]. Despite the excellent semen quality, fertility rates of frozen donkey semen in jennies are still low (0\%-36\%) [20-22] compared to mares (33\%-53\%) $[25,26]$. According to the available literature, the highest result of pregnancy using frozen donkey semen was reported by Rota et al. 2012. The authors achieved a conception rate of $61.5 \%$ for jennies inseminated with donkey semen cryopreserved in INRA-96, using glycerol and postthaw re-extended with seminal plasma (SP).

The reproductive biotechnologies performed in donkeys correspond to the same applied in horses [21,27]. Transferring the biotechnologies from one species to another often results in unsatisfactory results, probably because of physiological differences between the studied species [28]. There are some important distinctions in the biophysical parameters of cells among animals, such as the cell surface and volume, amount of intracellular water, and membrane permeability to water, thus requiring the development of specific protocols for each species [29].

The low fertility rates achieved in studies using frozen donkey semen in jennies indicate the necessity of further research to improve the semen cryopreservation techniques and AI protocols. Therefore, the aims of this study were: (1) to evaluate two freezing methods for the cryopreservation of donkey semen; (2) to determine a suitable insemination dose of fresh donkey semen for jennies and mares; and (3) to evaluate the influence of the semen deposition site on fertility of jennies inseminated with frozen donkey semen.

\section{Materials and methods}

This study was approved by the Ethics Committee of School of Veterinary Medicine and Animal Science, São Paulo State University (UNESP) and had ethical oversight from the same Institution.

\subsection{Experiment 1: Comparative evaluation of freezing methods for the cryopreservation of donkey semen}

\subsubsection{Semen collection and handling procedures}

A total of eight jacks (three Pega and five Brazilian Donkey jacks) aged between 8 and 15 years with proven fertility were used. Initially, the animals were collected for eight consecutive days to eliminate degenerated cells from the cauda epididymis and to stabilize the sperm parameters.

Two ejaculates were collected from each of eight donkeys using a Botucatu model artificial vagina (Botupharma, Brazil), with an interval of 3 days. After removal of the gel fraction, the semen was diluted in a skim milk based extender (BotuSemen; Botupharma) at a 1:1 ratio (vol:vol).

\subsubsection{Freezing methods}

After dilution, samples were centrifuged at $600 \times g$ for 10 minutes. The supernatants were discarded, and the sperm pellets were extended to a final concentration of $200 \times 10^{6}$ viable sperm/ $\mathrm{mL}$ in an egg yolk freezing extender (BotuCrio, Botupharma) and packaged into $0.5 \mathrm{~mL}$ straws. Then, semen samples were transferred to a refrigerator (Minitub do Brasil, Brazil) and remained at a constant temperature of $5{ }^{\circ} \mathrm{C}$ for 20 minutes [30]. After cooling, the straws were allocated into two groups, as follows: manual and automated method.

For the conventional method, an isothermal box (Styrofoam box) of 42-L capacity filled with a depth of 3.5$\mathrm{cm}$ liquid nitrogen $\left(\mathrm{N}_{2}\right)$ was used. The straws were placed horizontally at $6 \mathrm{~cm}$ above the level of $\mathrm{N}_{2}$ for 20 minutes. Subsequently, straws were immersed into liquid nitrogen for storage [30]. The freezing method used in this study was the same described by Maziero et al. [31]. The authors reported that the freezing curve in this system was $-10^{\circ} \mathrm{C} /$ min between $5{ }^{\circ} \mathrm{C}$ and $-60{ }^{\circ} \mathrm{C}$ and a velocity of $-8{ }^{\circ} \mathrm{C} / \mathrm{min}$ between $-60{ }^{\circ} \mathrm{C}$ and $-100{ }^{\circ} \mathrm{C}$.

For the automated system, after cooling at $5{ }^{\circ} \mathrm{C}$ for 20 minutes, the straws were submitted to freezing process using a velocity curve of $-15^{\circ} \mathrm{C} / \mathrm{min}$ from $5{ }^{\circ} \mathrm{C}$ to $-10^{\circ} \mathrm{C}$ and a velocity of $-40{ }^{\circ} \mathrm{C} / \mathrm{min}$ between $-10^{\circ} \mathrm{C}$ and $-140{ }^{\circ} \mathrm{C}$ (TK 4000C, TK Tecnologia em Congelação, Brazil).

\subsubsection{Semen evaluation}

The straws were thawed at $46^{\circ} \mathrm{C}$ for 20 seconds [32], and the motility parameters were evaluated by computerassisted sperm analisys (CASA; HTM IVOS 12; Hamilton Thorne Research, USA). The computer-assisted sperm analisys setup was the same described by others [33]. The plasma membrane integrity (PMI) was evaluated 
at $\times 400$ magnification by epi-fluorescence microscopy (Leica Microsystems, DMLB, Wetzlar, Germany) using the fluorescent probes carboxyfluorescein diacetate and propidium iodide as described by Harrison and Vickers [34]. Two hundred sperm cells were counted per sample for PMI.

\subsection{Experiment 2: Effect of insemination dose of fresh donkey} semen on fertility of jennies and mares

\subsubsection{Animals}

A Brazilian Donkey jack with proven fertility, 15 mares of different breeds (five Mangalarga Marchador, five Brazilian Sport Horse, and five Breton), and 15 Brazilian Donkey jennies were included in this study, totalizing 15 estrous cycles of mares and 30 estrous cycles of jennies.

\subsubsection{Semen collection and handling procedures}

Semen was collected preceding the experiment to deplete extragonadal sperm reserves as described in Section 2.1.1. After that, the raw semen was diluted in a skim milk based extender (BotuSemen, Botupharma) to a concentration of $500 \times 10^{6}$ or $1 \times 10^{9}$ viable sperm in a final volume of $15 \mathrm{~mL}$.

\subsubsection{Breeding management and $A I$}

The jennies and mares were monitored daily by transrectal palpation and ultrasonography to follow the ovarian activity. When the largest follicle reached a diameter of 33 to $35 \mathrm{~mm}$, the females were inseminated in the uterine body (UB) every 48 hours until the detection of ovulation.

Three groups of AIs using fresh donkey semen were performed. One estrous cycle of each mare was used for the insemination of $500 \times 10^{6}$ viable sperm (M, 15 cycles), and two estrous cycles from each jenny were randomly assigned to the insemination group of $1 \times 10^{9}$ viable sperm (J1, 15 cycles) or $500 \times 10^{6}$ viable sperm (J5, 15 cycles).

Pregnancy diagnosis was performed 15 days after the detection of ovulation by transrectal palpation and ultrasonography (DP-2200Vet, Mindray, Brazil) through the presence of the embryonic vesicle. In the case of negative diagnosis, the evaluation was repeated after 24 hours. All females were given $5 \mathrm{mg}$ intramuscular dinoprost (Lutalyse, Pfizer, Brazil) to terminate the pregnancy.

\subsection{Experiment 3: Effect of insemination site of frozen donkey semen on fertility of jennies}

\subsubsection{Animals, semen collection, and handling process}

A Pega Donkey jack with proven fertility and 28 jennies (five Pega; 23 Brazilian Donkey) were used for this study, totalizing 58 estrous cycles.

Semen collection and handling procedures are described in Section 2.1.1. The semen was frozen using the automated system as described in Section 2.1.2.

\subsubsection{Breeding management and AI}

The breeding management was the same described in Section 2.2.3. However, when a follicle reached 33 to $35 \mathrm{~mm}$ in diameter, the ovulation was induced with 1-mg deslorelin acetate (Botupharma), intramuscular.
The jennies were divided into two insemination groups according to the semen deposition site: uterine body (UB; 12 estrous cycles from eight jennies); and tip of the uterine horn (UH) adjacent to the preovulatory follicle by deep horn insemination technique (UH; 46 estrous cycles from 20 jennies).

2.3.3. Multiple inseminations in the $U B$ or at the tip of the $U H$ The straws were thawed at $46{ }^{\circ} \mathrm{C}$ for 20 seconds [32]. The inseminations were performed 24 hours after induction of ovulation and every 8 hours until the detection of ovulation. The jennies that ovulated before 24 hours after the induction of ovulation were not inseminated. The cycles in which jennies ovulated later than 60 hours after induction of ovulation were excluded of this experiment.

The frozen-thawed semen was deposited in the UB or at the tip of the UH with a 75-cm flexible pipette (Minitub of Brazil, Brazil) and an appropriate applicator, with dose of $1 \times 10^{9}$ viable sperm (10 straws) per insemination.

Pregnancy diagnosis is described in Section 2.2.3.

\section{Statistical analysis}

Data from experiment 1 , were analyzed by analysis of variance followed by Tukey's test to identify the significant differences. Data from experiments 2 and 3 were analyzed by Fisher's exact test to find statistical differences between pregnancy rates in different groups. Statistical analyses were performed using GraphPad Prism version 4.00 for Windows, GraphPad Software, San Diego California USA, www.graphpad.com. Treatments were considered different if $\mathrm{P}<0.05$.

\section{Results}

\subsection{Experiment 1: Comparative evaluation of freezing methods for the cryopreservation of donkey semen}

The sperm parameters evaluated of 32 semen samples from eight donkeys by conventional and automated methods are described in Table 1.

No differences were observed between treatments for total motility (TM), angular velocity, curvilinear velocity, straight-line velocity, and PMI. However, progressive motility (PM) and rapid cells (RAP) parameters were significantly higher $(P<0.05)$ in samples frozen in the automated method when compared to the conventional method.

\subsection{Experiment 2: Effect of insemination dose of fresh donkey semen on fertility of jennies and mares}

Two to four AIs were performed per cycle in each treatment, as described in Table 2.

Pregnancy rates at Day 15 postovulation for the different treatments are described in Table 3. No significant difference was observed between the conception rates of mares and jennies using the insemination dose of $500 \times 10^{6}$ or $1 \times 10^{9}$ viable sperm, respectively. There was no statistical difference between the two different insemination doses on jennies (J1 and J5). However, when the same insemination 
Table 1

Mean values and standard deviations of the sperm parameters TM, PM, VAP, VSL, VCL, RAP, and PMI of donkey semen frozen by conventional (Styrofoam box) and automated system (TK 4000C).

\begin{tabular}{|c|c|c|c|c|c|c|c|}
\hline Freezing techniques & TM (\%) & PM (\%) & $\mathrm{VAP}(\mu \mathrm{m} / \mathrm{s})$ & $\mathrm{VCL}(\mu \mathrm{m} / \mathrm{s})$ & $\mathrm{VSL}(\mu \mathrm{m} / \mathrm{s})$ & RAP (\%) & PMI (\%) \\
\hline Conventional & $64.3 \pm 2.9$ & $39.9 \pm 2.6^{\mathrm{a}}$ & $83.9 \pm 3.6$ & $158.6 \pm 5.5$ & $52.1 \pm 1.9$ & $48.3 \pm 3.7^{a}$ & $42.9 \pm 2.7$ \\
\hline Automated & $65.3 \pm 2.9$ & $44.5 \pm 3.9^{b}$ & $84.4 \pm 2.8$ & $161.9 \pm 4.4$ & $52.1 \pm 1.9$ & $50.9 \pm 3.0^{b}$ & $43.1 \pm 3.0$ \\
\hline
\end{tabular}

${ }^{\mathrm{a}, \mathrm{b}}$ Different letters in a column indicate differences $(\mathrm{P}<0.05)$.

Data are mean \pm standard deviation $(\mathrm{n}=8)$.

Abbreviations: PM, progressive motility; PMI, plasma membrane integrity; RAP, rapid cells; TM, total motility; VAP, angular velocity; VCL, curvilinear velocity; VSL, straight-line velocity.

dose was used, $500 \times 10^{6}$ sperm, the pregnancy rates were higher for mares compared to jennies $(P<0.05)$.

\subsection{Experiment 3: Effect of insemination site of frozen donkey jack semen on fertility of jennies}

Three to five Als were performed per cycle in each treatment, as described in Table 4.

Pregnancy rates at Day 15 postovulation for the different sites of insemination are described in Table 5. No pregnancies were obtained with inseminations of $1 \times 10^{9}$ viable sperm in the UB of jennies (UB; 0/12). However, when the semen was deposited at the tip of the UH by deep horn insemination, conception rates reached $28.26 \%(13 / 46)$. Thus, the inseminations of frozen donkey semen at the tip of the UH achieved higher pregnancy rates in comparison with inseminations performed in UB, using multiple insemination doses of $1 \times 10^{9}$ sperm $(\mathrm{P}<0.05)$.

\section{Discussion}

The development of optimal freezing rates for sperm cells has been studied in several species [31,35-37]. In this study, the sperm motility parameters of TM, angular velocity, curvilinear velocity, straight-line velocity, and PMI showed no differences between conventional and automated freezing methods. However, the values of PM and RAP were higher on samples frozen by automated method compared to conventional method. These findings differ from those of other researchers [31] who reported no difference in the evaluated sperm parameters and PMI in equine semen frozen by conventional or automated method.

\section{Table 2}

Number of artificial inseminations (AIs) performed in the uterine body with fresh donkey semen per cycle within different treatments, after detection of a follicle with 33 to $35 \mathrm{~mm}$ in diameter and every 48 hours until ovulation.

\begin{tabular}{lllr}
\hline Insemination dose & $\begin{array}{l}\text { Number } \\
\text { of AI }\end{array}$ & $\begin{array}{l}\text { Number } \\
\text { of cycles }\end{array}$ & $\begin{array}{l}\text { Total sperm } \\
\text { inseminated }\end{array}$ \\
\hline Mares & & & $1 \times 10^{9}$ \\
$500 \times 10^{6}$ sperm/AI (M) & 2 & 6 & $1.5 \times 10^{9}$ \\
& 3 & 6 & $2 \times 10^{9}$ \\
Jennies & 4 & 3 & $2 \times 10^{9}$ \\
$1 \times 10^{9}$ sperm/AI (J1) & 2 & 6 & $3 \times 10^{9}$ \\
& 3 & 6 & $4 \times 10^{9}$ \\
$500 \times 10^{6}$ sperm/AI (J5) & 4 & 3 & $1.5 \times 10^{9}$ \\
& 2 & 8 & $2 \times 10^{9}$ \\
\hline
\end{tabular}

In relation to the freezing rate, the use of a rapid freezing rate in the automated system increased the sperm parameters of TM, PM, and RAP of "bad freezer" stallions semen [35]. In boars, the rapid freezing rate $\left(-40^{\circ} \mathrm{C} / \mathrm{min}\right)$ in the automated system improved the sperm motility parameters and PMI compared to slow freezing rate $\left(-6^{\circ} \mathrm{C} /\right.$ min) [36]. Similarly, it is possible that the higher results of PM and RAP achieved in the automated method were due to the use of a rapid freezing rate, since the programmable system may provide a higher and more consistent freezing rate in comparison with the isothermal box.

The sperm motility is a necessary function for fertilization because it is important for sperm transport through specific sites in the female reproductive tract [38,39], through the cumulus [40], and for the penetration of the zona pellucida [41]. In humans, the reduction of progressive motility in frozen semen is one of the main indicators of cryodamage, which can result in low fertility rates [42]. Thus, in contrast, the higher values of progressive motility and rapid sperm found in samples frozen by automated method in this study may reflect better pregnancy rates.

The pregnancy rate of mares inseminated with fresh donkey semen using $500 \times 10^{6}$ viable sperm resulted in $93 \%$ conception rate (experiment 2 ), and it was higher from that found by others $[43,44]$. Palhares et al. [43] obtained $57 \%$ of pregnancy rate using $300 \times 10^{6}$ sperm, and Silva [44] reported $52.4 \%, 52.2 \%$, and $68.5 \%$ of pregnancy rates in three consecutive breeding seasons, using $500 \times 10^{6}$ sperm.

The superior results on pregnancy rates obtained in the present study may be related to several factors. In equine species, it is reported a large variability between ejaculates and stallions [45], such as the protein composition of sperm membrane among individuals [46], ejaculates [47], and different ejaculate fractions [48]. In donkeys, there is a high variability between individuals on sperm morphology [49]. Schmidt et al. [50] compared the SP protein profile of stallions and donkeys jacks. The authors found 10 similar bands with the same molecular weight $(11-30 \mathrm{kDa})$ in both species, suggesting similarity on SP composition between

Table 3

Effect of insemination dose of fresh donkey semen in the uterine body on fertility of mares and jennies.

\begin{tabular}{lllll}
\hline Groups & Females & $\begin{array}{l}\text { Estrous } \\
\text { cycles }\end{array}$ & $\begin{array}{l}\text { Insemination dose } \\
\text { (viable sperm) }\end{array}$ & $\begin{array}{l}\text { Conception } \\
\text { rates }(\%)\end{array}$ \\
\hline $\mathrm{M}$ & Mares & 15 & $500 \times 10^{6}$ & $14 / 15(93 \%)^{\mathrm{a}}$ \\
$\mathrm{J} 1$ & Jennies & 15 & $1 \times 10^{9}$ & $11 / 15(73 \%)^{\mathrm{a}, \mathrm{b}}$ \\
$\mathrm{J} 5$ & Jennies & 15 & $500 \times 10^{6}$ & $6 / 15(40 \%)^{\mathrm{b}}$ \\
\hline
\end{tabular}

${ }^{\mathrm{a}, \mathrm{b}}$ Different letters in a column indicate differences $(\mathrm{P}<0.05)$. 
Table 4

Number of artificial inseminations (AIs) performed in the uterine body and at the tip of the uterine horn with frozen donkey semen per cycle within different treatments, 24 hours after induction of ovulation and every 8 hours until the detection of ovulation.

\begin{tabular}{clcc}
\hline Insemination dose & $\begin{array}{l}\text { Number } \\
\text { of AI }\end{array}$ & $\begin{array}{l}\text { Number } \\
\text { of cycles }\end{array}$ & $\begin{array}{l}\text { Total sperm } \\
\text { inseminated }\end{array}$ \\
\hline Uterine body (UB) & & 8 & $4 \times 10^{9}$ \\
$1 \times 10^{9}$ sperm/AI & 4 & 4 & $5 \times 10^{9}$ \\
Uterine horn (UH) & 5 & & $3 \times 10^{9}$ \\
$1 \times 10^{9}$ sperm/AI & 3 & 3 & $4 \times 10^{9}$ \\
& 4 & 5 & $5 \times 10^{9}$ \\
\hline
\end{tabular}

donkeys and stallions. Considering these previous reports, it is possible that there is an individual variation on semen quality on jacks as observed on stallions, which may have influenced the pregnancy rates achieved in this study.

With an insemination dose of $500 \times 10^{6}$ fresh sperm, the pregnancy rates were significantly higher in mares than in jennies However, when the number of sperm cells per insemination dose was increased to $1 \times 10^{9}$ sperm in J1 (jennies), no difference was found between conception rates of jennies and mares. In pasture conditions, a high number of matings of individuals jennies (up to 18 times) is performed during estrous period, and the total number of sperm in donkey ejaculated is approximately $10 \times 10^{9}$ total sperm [51]. Considering that the mating is held for many times in the same jennie, it is suggested that a high number of spermatozoa is needed to ensure the fertilization. This hypothesis is supported by the similar pregnancy rates observed in mares and jennies using a higher insemination dose in jennies.

Furthermore, in experiment 2, the inseminations were performed in the UB when the largest follicle reached a diameter of 33 to $35 \mathrm{~mm}$ and every 48 hours until the detection of ovulation. Most of females (mares and jennies) were inseminated two or three times in all groups, receiving a total of 1 to $1.5 \times 10^{9}$ sperm in $\mathrm{M}$ and J5 and 2 to $3 \times 10^{9}$ sperm in J1 (Table 2 ). As the number of inseminated sperm in J1 was higher ( 2 to $3 \times 10^{9}$ sperm) than that usually used in conventional inseminations $\left(500 \times 10^{9}\right.$ sperm) and achieved $73 \%$ of pregnancy rate, it is suggested that the number of sperm used in the conventional inseminations is not enough to reach the ideal sperm population to proceed the fertilization process in this species.

As reported, the fertility rates of frozen donkey semen on jennies are still low (0\%-36\%) [20-22] when compared to mares (33-43\%) [25,26]. The use of frozen donkey semen

Table 5

Effect of insemination site of frozen donkey semen on conception rates of jennies inseminated 24 hours after induction of ovulation induction and every 8 hours until ovulation with $1 \times 10^{9}$ viable sperm.

\begin{tabular}{llll}
\hline $\begin{array}{l}\text { Insemination } \\
\text { site }\end{array}$ & $\begin{array}{l}\text { Estrous } \\
\text { cycles }\end{array}$ & $\begin{array}{l}\text { Insemination dose } \\
\text { (viable sperm) }\end{array}$ & $\begin{array}{l}\text { Conception } \\
\text { rates (\%) }\end{array}$ \\
\hline Uterine body (UB) & 12 & $1 \times 10^{9}$ & $0 / 12(0 \%)^{\mathrm{a}}$ \\
Uterine horn (UH) & 46 & $1 \times 10^{9}$ & $13 / 46(28,26 \%)^{\mathrm{b}}$ \\
\hline
\end{tabular}

${ }^{\mathrm{a}, \mathrm{b}}$ Different letters in a column indicate differences $(\mathrm{P}<0.05)$. results in satisfactory pregnancy rates in mares but apparently has difficulty to fertilize the oocyte of jennies. In this study, the use of frozen donkey semen in jennies performed by deep horn insemination resulted in a conception rate of $28.26 \%$. According to the available literature, the highest result of pregnancy rates using donkey frozen semen was reported by Rota et al. [13]. The authors achieved $61.5 \%$ of conception rate in jennies inseminated with donkey semen cryopreserved in INRA-96, using glycerol as cryoprotectant and postthaw re-extended with SP.

The SP plays several roles on sperm metabolism and fertilization [52-54]. In addition, SP mediates the postcoital inflammatory response in the uterus of mares [55]. During cryopreservation process, SP is removed from the semen, leaving approximately $0 \%$ to $5 \%$ of the original SP [56]. The dilution of frozen-thawed donkey semen in SP before AI displays a trend toward the improvement of fertility to improve pregnancy rates [13].

The equine SP suppresses polymorphonuclear neutrophil (PMN) chemotaxis, PMN phagocytosis, and hemolytic complement activity in vitro [57]. The cysteine-rich secretory protein 3 is an abundant constituent of equine SP and is related to sperm elimination from the female reproductive tract [58] and to a positive relationship with stallion fertility, as previously reported $[59,60]$. In the jennie, as in the mare, AI induces an inflammatory uterine response mainly characterized by the presence of PMN [55]. Miró et al. [23] observed that the absence of SP in frozen-thawed donkey semen enhanced the inflammatory activity of PMN in vitro. The low pregnancy rates found in this study, may be related to the absence of SP and/or the uterine inflammatory response to frozen-thawed donkey spermatozoa. However, it is not possible to confirm this hypothesis in the present study because the postbreeding endometritis event was not evaluated.

As reported in others studies [20-22], the glycerol may have a toxic effect on donkey sperm because the presence of this molecule in the cooling or freezing extenders affected the fertility in jennies. The commercial equine semen freezing extender (BotuCrio) used in this study use a combination of dimethylformamide and glycerol. Vidament et al. [22] reported that the replacement of glycerol by $2 \%$ dimethylformamide increased the fertility in jennies with cooled donkey semen but did not increase the fertility with frozen-thawed donkey semen. The association of these cryoprotectants in the freezing extender used in this study may have positively influenced the fertility rate of frozen donkey semen deposited at the tip of the $\mathrm{UH}$ (28.26\%). In contrast, when the frozen-thawed semen was deposited in the UB no pregnancy was achieved. Likewise, low conception rates were found on inseminations in the UB using frozen donkey semen with $2.2 \%$ glycerol $\left(800 \times 10^{6}\right.$ sperm; $\left.11 \%\right)$ or $2.2 \%$ dimethylformamide $\left(400 \times 10^{6}\right.$ sperm; $\left.10.7 \%\right)$ [22].

Once the conception rates were higher in the deep horn inseminations as compared to UB AI, it is also suggested that the pregnancy rates may be affected by the site of insemination. In the mare, the sperm reservoir is established in the oviduct approximately 4 hours from the time of insemination [61]. Although there are no studies on the sperm transport in the jennies. It is possible that the deep 
horn inseminations allowed a lower time of interaction between sperm cells and the endometrium, leading to reduced uterine inflammatory response and increased number of viable sperm and a closer proximity to the site of sperm storage and fertilization.

The multiple inseminations performed in this study may have played a role as a "compensatory factor" to the deleterious effect of the interaction between the spermatozoa and the female reproductive tract. For the frozen donkey semen, the insemination dose of $1 \times 10^{9}$ sperm was performed four times per cycle until detection of ovulation ( $\sim 4 \times 10^{9}$ sperm/cycle $)$. The increased number of inseminations per cycle ( 4 insemination doses of $1 \times 10^{9}$ sperm) may have provided a greater number of viable sperm on the oviduct to proceed fertilization, supporting the hypothesis that is necessary a high sperm concentration to obtain pregnancy in jennies, as in natural conditions.

In conclusion, the results in this study demonstrate that: (1) the freezing of donkey semen by automatic method achieved better results in some sperm kinetic parameters than that in the conventional method and can be used as an alternative for freezing donkey semen; (2) the increase in the number of sperm cells per insemination dose using fresh donkey semen improved the fertility rates in jennies and allowed to achieve similar pregnancy rates obtained in mares; and (3) the deep horn inseminations using frozenthawed donkey semen increased the pregnancy rate in jennies, and the multiple inseminations may be an option to improve the fertility rates of donkey semen in jennies.

\section{Acknowledgments}

We acknowledge the São Paulo Research Foundation (FAPESP) for the financial support.

\section{Competing Interests}

None.

\section{References}

[1] Gastal MO, Henry M, Beker AR, Gastal EL, Gonçalves A. Sexual behavior of donkey jacks: influence of ejaculatory frequency and season. Theriogenology 1996;46:593-603.

[2] Canisso IF, Carvalho GR, Davies Morel MCG, Guimarães JD, McDonnell SM. Sexual behavior and ejaculate characteristics in Pêga donkeys (Equus asinus) mounting estrous horse mares (Equus caballus). Theriogenology 2010;73:56-63.

[3] McLeana AK, Heleskib CR, Yokoyamab MT, Wangc W, Doumbiad A Dembelee B. Improving working donkey (Equus asinus) welfare and management in Mali, West Afr. J Vet Behav 2012;7:123-34.

[4] Sanchez R, Gomez I, Samper JC. Artificial insemination with frozen semen. In: Samper JC, editor. Equine breeding, management and artificial insemination. St. Louis: WB Sauders Elsevier; 2009. p. 175-83.

[5] Kugler W, Grunenfelder HP, Broxham E. Donkey breeds in Europe. St. Gallen, Switzerland: Monitoring institute for rare breeds and seeds in Europe; 2008.

[6] FAO: Molecular-genetic characterization of animal genetic resources. Rome, Italy: Food and Agriculture Organization; 2011.

[7] Folch P, Jordana J. Characterization, reference ranges and the influence of gender on morphological parameters of the endangered Catalonian donkey breed. J Equine Vet Sci 1997;17:102-11.

[8] Marshburn PB, McIntire D, Carr BR, Byrd W. Spermatozoal characteristics from fresh and frozen donor semen and their correlation with fertility outcome after intrauterine insemination. Fertil Steril 1992;58:179-86.

[9] Samper JC, Morris CA. Current methods for stallion semen cryopreservation: a survey. Theriogenology 1998;49:895-903.

[10] Watson PF. The causes of reduced fertility with cryopreservation semen. Anim Reprod Sci 2000;60:481-92.

[11] Blach EL, Amann RP, Bowen RA, Frantz D. Changes in quality of stallion spermatozoa during cryopreservation: plasma membrane integrity and motion characteristics. Theriogenology 1989;31:283-98.

[12] Watson PF. Recent developments and concepts in the cryopreservation of spermatozoa and the assessment of their postthawing function. Reprod Fertil Dev 1995;7:871-91.

[13] Rota A, Panzani D, Sabatini C, Camillo F. Donkey jack (Equus asinus) semen cryopreservation: studies of seminal parameters, post breeding inflammatory response, and fertility in donkey jennies. Theriogenology 2012;78:1846-54.

[14] Kotilainen T, Huhtinen M, Katila T. Sperm-induced leukocytosis in the equine uterus. Theriogenology 1994;41:629-36.

[15] Barker CAV, Gaudier JCC. Pregnancy in a mare resulting from frozen epididymal spermatozoa. Can J Comp Med Vet Sci 1957;21:47-51.

[16] Amann RP, Pickett BW. Principles of cryopreservation and a review of cryopreservation of stallion spermatozoa. J Equine Vet Sci 1987;7: 145-73.

[17] Samper JC. Management and fertility of mares bred with frozen semen. Anim Reprod Sci 2001;68:219-28.

[18] Loomis PR, Squires EL. Frozen semen management in equine breeding programs. Theriogenology 2005;64:480-91.

[19] Avanzi BR, Ramos RS, Araujo GHM, Fioratti EG, Trinca LA, Dell'Aqua Jr JA, et al. Theriogenology 2015;83:1389-93.

[20] Trimeche A, Renard P, Tainturier D. A procedure for poitou jackass sperm criopreservation. Theriogenology 1998;50:793-806.

[21] Oliveira JV, Alvarenga MA, Melo CM, Macedo LM, Dell"Aqua jr JA, Papa FO. Effect of cryoprotectant on donkey semen freezability and fertility. Anim Reprod Sci 2006;94:82-4.

[22] Vidament M, Vincent P, Martin FX, Magistrini M, Blesbois E. Differences in ability of jennies and mares to conceive with cooled and frozen semen containing glycerol or not. Anim Reprod Sci 2009; $112: 22-35$.

[23] Miró J, Vilés K, García W, Jordana J, Yeste M. Effect of donkey seminal plasma on sperm movement and spermpolymorphonuclear neutrophils attachment in vitro. Anim Reprod Sci 2013;140:164-72.

[24] Ortiz I, Dorado J, Morrell JM, Crespo F, Gosálvez J, Gálvez MJ, et al. Effect of single-layer centrifugation or washing on frozen-thawed donkey semen quality: do they have the same effect regardless of the quality of the sample? Theriogenology 2015;84:294-300.

[25] Vieira RC, Arruda RP, Manzano A. Inseminação intercornual comsêmen congelado em palhetas de 0.5 ml. Proc Ann Soc Zootec 1985; $22: 298$.

[26] Canisso IF, Carvalho GR, Morel MD, Ker PG, Rodrigues AL, Silva EC, et al. Seminal parameters and field fertility of cryopreserved donkey jack semen after insemination of horse mares. Equine Vet J 2011;43:179-83.

[27] Camillo F, Panzani D, Scollo C, Rota A, Crisci A, Vannozzi I, et al. Embryo recovery rate and recipients' pregnancy rate after nonsurgical embryo transfer in donkeys. Theriogenology 2010;73:959-65.

[28] Wildt DE, Pukazhenti B, Brown J, Monfort S, Howard JG, Roth T. Spermatology for understanding, managing and conserving rare species. Reprod Fertil Dev 1995;7:811-24.

[29] Curry MR. Cryopreservation of semen from domestic livestock. Rev Reprod 2000;5:46-52.

[30] Papa FO, Melo CM, Fioratti EG, Dell'aqua jr JA, Zahn FS, Alvarenga MA. Freezing of stallion epididymal sperm. Anim Reprod Sci 2008;107:293-301.

[31] Maziero RRD, Guasti PN, Monteiro GA, Avanzi BR, Hartwig FP Lisboa FP, et al. Evaluation of sperm kinetics and plasma membrane integrity of frozen equine semen in different storage volumes and freezing conditions. J Equine Vet Sci 2013;33:165-8.

[32] Dell'aqua JA, Papa FO, Alvarenga MA, Zahn FS. Effects of warming rate on sperm parameters and of insemination site and dose on the fertility of equine frozen semen. Anim Reprod Sci 2001;68:344-6.

[33] Guasti PN, Monteiro GA, Maziero RRD, Martin I, Avanzi BR, Dellaqua Jr JA, et al. Effects of pentoxifylline on equine epididymal sperm. J Equine Vet Sci 2013;33:1153-6.

[34] Harrison RAP, Vickers SE. Use of fluorescent probes to assess membrane integrity in mammalian spermatozoa. J Reprod Fertil 1990;88:343-52.

[35] De Vita B. Estudo de diferentes sistemas e curvas de congelação na eficiência da congelabilidade e fertilidade de sêmen eqüino. Master 
of Science Thesis. Botucatu: Faculdade de Medicina Veterinaria e Zootecnia, UNESP; 2008.

[36] Thurston LM, Holt WW, Watson PF. Post-thaw functional status of boar spermatozoa cryopreserved using three controlled rate freezers: a comparison. Theriogenology 2003;60:101-13.

[37] Comparison between the conventional and automated systems of semen bovine cryopreservation. Ciênc Anim Bras 2014;15:32-7.

[38] Troedsson MH, Liu IK, Crabo BG. Sperm transport and survival in the mare: a review. Theriogenology 1998:50:807-18.

[39] Fiala SM. Sperm transport in the mare reproductive tract: a review. IJAS 2012;2:305-9.

[40] Talbot P, DiCarlantonio G, Zao P, Penkala J, Haimo LT. Motile cells lacking hyaluronidase can penetrate the hamster oocyte cumulus complex. Dev Biol 1985;108:387-98.

[41] Yanagimachi R. Mechanisms of fertilization in mammals. In: Mastroianni L, Biggers JD, editors. Fertilization and embryonic development in vitro. New York: Plenum Press; 1981. p. 81-182.

[42] Oehninger S, Duru NK, Srisombut C, Morshedi M. Assessment of sperm cryodamage and strategies to improve outcome. Mol Cell Endocrinol 2000;169:3-10.

[43] Palhares MS, Silva Filho JM, Oliveira Jr EF. Inseminação artificial em jumentas da raça pega com cio induzido pelo Dinoprost. Rev Bras Reprod Anim 1986;10:157-63.

[44] Silva MIF. Viabilidade do uso da inseminação artificial em eqüinos ao nível industrial. In: Congresso Brasileiro de Reprodução Animal, v.7. Belo Horizonte: Colégio Brasileiro de Reprodução Animal; 1998. p.47-63.

[45] Tejerina F, Morrell J, Petterson J, Dalin A-M, Rodriguez-Martinez H. Routine assessment of motility of ejaculated stallion spermatozoa using a novel computer-assisted motility analyzer (Qualisperm ${ }^{\mathrm{TM}}$ ). Anim Reprod 2009;6:380-5.

[46] Zahn FS, Papa FO, Melo CM. Blood serum, seminal plasma and sperm membrane protein profiles in stallions: are they correlated to semen freezability? Anim Reprod Sci 2006;94:64-6.

[47] Frazer GS, Bucci DM. Characterization of the major polypeptides of equine seminal plasma by two-dimensional polyacrylamide gel electrophoresis. Theriogenology 1996;46:1389-402.

[48] Kareskoski AM, Rivera del Alamo MM, Guvenc K, Reilas T, Calvete JJ, Rodriguez-Martinez $\mathrm{H}$, et al. Protein composition of seminal plasma in fractionated stallion ejaculates. Reprod Domest Anim 2011;46: 79-84.

[49] Gloria A, Contri A, Amicis I, Robbe D, Carluccio A. Differences between epididymal and ejaculated sperm characteristics in donkey. Anim Reprod Sci 2011;128:117-22.
[50] Schmith RA, Scott C, Camargo LS, Guasti PN, Freitas GL, Souza, FF. Comparação do perfil proteico do plasma seminal de equus caballus e equus asinus por eletroforese unidimensional. In: Conferência Anual da ABRAVEQ 2015, Águas de Lindóia. XVI Conferência Anual da ABRAVEQ - Programas e Resumos, 2015.

[51] Henry M, McDonnell SM, Lodi LD, Gastal EL. Pasture mating behaviour of donkeys (Equus asinus) at natural and induced oestrus. J Reprod Fertil 1991;44:77-86.

[52] Thérien I, Manjunath P. Effect of progesterone on bovine sperm capacitation and acrosome reaction. Biol Reprod 2003;69: $1408-15$.

[53] Yoshida M, Kawano N, Yoshida K. Control of sperm motility and fertility: diverse factors and common mechanisms. Cell Mol Life Sci 2008;65:3446-57.

[54] Gwathmey TM, Ignotz GG, Mueller JL, Manjunath P, Suarez SS. Bovine seminal plasma proteins PDC-109, BSP-A3, and BSP-30 kDa share functional roles in storing sperm in the oviduct. Biol Reprod 2006; $75: 501-7$.

[55] Troedsson MHT, Desvouges AL, Hansen PJ, Buhi WC. Equine seminal plasma proteins protect live spermatozoa from PMN-binding and phagocytosis, while providing a mechanism for selective sperm elimination of apoptotic and dead spermatozoa. Anim Reprod Sci 2006;94:60-1.

[56] Moore AI, Squires EL, Graham JK. Effect of seminal plasma on the cryopreservation of equine spermatozoa. Theriogenology 2005;63: 2372-81.

[57] Troedsson MHT, Lee CS, Franklin RD, Crabo BG. The role of seminal plasma in post-breeding uterine inflammation. J Reprod Fertil Suppl 2000;56:341-9.

[58] Doty A, Buhi WC, Benson S, Scoggin KE, Pozor M Macpherson M, et al. Equine CRISP3 modulates interaction between spermatozoa and polymorphonuclear neutrophils. Biol Reprod 2011;85:157-64.

[59] Hamann H, Jude R, Sieme H, Mertens U, Töpfer-petersen E, Distl O, et al. A polymorphism within the equine CRISP3 gene is associated with stallion fertility in Hanoverian warmblood horses. Anim Genet 2007;38:259-64

[60] Novak S, Smith TA, Paradis F, Burwash L, Dyck MK, Foxcroft GR, et al. Biomarkers of in vivo fertility in sperm and seminal plasma of fertile stallions. Theriogenology 2010;74: 956-67.

[61] Scott M. A glimpse at sperm function in vivo: sperm transport and epithelial interaction in the female reproductive tract. Anim Reprod Sci 2000;60-61:337-48. 